\title{
The Hadrami Diaspora: A "Diaspora For Others" IN THE INDIAN OCEAN ${ }^{1}$
}

\author{
Iain Walker \\ Max Planck Institute for Social Anthropology
}

\begin{abstract}
The term diaspora has, over the past two decades, become ubiquitous both in the vernacular and in academia, to the point that it appears to have lost its acuity as an analytical concept, often meaning little more than a group of migrants. In an attempt to reinvigorate the concept, this article invokes the notion of the "diaspora for others": a diaspora that has a coherence across space and time, linking the various localisations of a diaspora, and the homeland. The case study is the Hadrami diaspora, and by tracing the links between members of the diaspora, this article demonstrates how the diaspora, although marked by internal differences, nevertheless displays an overall cohesion that grants it a stable and distinct identity as a spatially dispersed community, thus recalling the original sense of the term diaspora.
\end{abstract}

\footnotetext{
${ }^{1}$ This article has evolved from papers presented at the "Islam and the Hadrami diaspora in the eastern and western Indian Ocean" symposium (Leiden, December 2014), the Hadhramaut Research Centre inaugural conference "Rediscovering Hadhramaut" (SOAS, March 2015), "The Impact of Diasporas" conference organised jointly by the Oxford Diasporas Programme and the University of Leicester's Impact of Diasporas on the Making of Britain programme (RGS, London, September 2015), and my own conference "Us and them: Diasporas for others in the Indian Ocean", held in Halle in 2019, and from which this special issue emerged. I would like to thank participants at all these events for their comments, particularly Martin Slama, as well as the editors and two anonymous referees of this journal.

More than two decades of research on Hadramis the length of the western Indian Ocean littoral (and occasionally inland) has been funded by the Australian Research Council, the Economic and Social Research Council, and the Leverhulme Trust (in the guise of the Oxford Diasporas Programme), amongst others, and greatly facilitated by the American Institute for Yemeni Studies, the Centre Français de Recherche de la Péninsule Arabique, both in San'a', and the King Faisal Centre for Research and Islamic Studies in Riyadh, and I would like to express my gratitude to all these bodies, and to all my friends and collaborators both in Hadramawt and elsewhere, and particularly Ahmed Basaiba.
}

(C) Iain Walker. This is an Open Access article distributed under the terms of the Creative Commons License CC BY NC SA, which permits users to share, use, and remix the material provided they give proper attribution, the use is noncommercial, and any remixes/transformations of the work are shared under the same license as the original. 


\section{INTRODUCTION}

It's July 1969 and the Eagle has just landed. Neil Armstrong opens the module door and carefully descends the ladder to the lunar surface. Taking one small step for (a) man, he finally stands on the moon and says, "one giant leap for mankind." He turns away from the ladder, looks around and recoils in surprise. Half a dozen men are rushing towards him across the lunar plain. They're Hadramis, and they're all looking for a job.

For various reasons - famine, disease, and civil unrest, but also for religious purposes, commerce and trade, and following kin - Hadramawt, on the south coast of the Arabian Peninsula, has long been a land of emigration. And, as the above joke, told to me on numerous occasions by Hadramis in various parts of the world, suggests, emigration is a part of Hadrami culture: Hadramis are well aware of their migratory tendencies and almost everyone in Hadramawt seems to have kin elsewhere, part of a diaspora that historically extended from Mauritania to Indonesia and from South Asia to Madagascar. Certainly, there have been shifts in migratory flows, moments when emigration has increased, other moments when, for one reason or another, it has slowed; but the pattern, in the longue durée, has been one of regular outflows. ${ }^{2}$

However, if emigration remains prominent in the popular imagination (and in censuses around the Indian Ocean), there are returns, too: the homeland remains a part of the Hadrami worldview, and Hadrami movements are marked by comings as well as goings. The relationship with the homeland is enduring, both in terms of imaginaries, memories, histories and social narratives, but physically, too: people leave Hadramawt, and people return. Some of these movements are short term - visits of weeks or even days - others are longer - sojourns of several years to permanent returns for retirement. Hadramawt is a land to which its people are drawn: by sites, both holy and personal, such as tombs, or by a desire to retire "back home;" kin links and, occasionally, economic

\footnotetext{
${ }^{2}$ See, for example: Ahmed Ibrahim Abushouk and Hassan Ahmed Ibrahim (eds.), The Hadhrami Diaspora in Southeast Asia: Identity maintenance or assimilation? (Leiden: Brill, 2009); Noel Brehony (ed.), Hadhramaut and its Diaspora: Yemeni politics, identity and migration (London: I. B. Tauris, 2017); Huub de Jonge and Nico Kaptein (eds.) Transcending Borders: Arabs, politics, trade and Islam in Southeast Asia (Leiden: KITLV Press, 2002); Ulrike Freitag and William Gervase Clarence-Smith (eds.), Hadhrami Traders, Scholars and Statesmen in the Indian Ocean, 1750s-1960s (Leiden: Brill, 1997); Christian Lekon, Time, Space and Globalization Hadhramaut and the Indian Ocean Rim, 1863-1967 (Gleichen: Muster-Schmidt Verlag, 2014); Leif Manger, The Hadrami Diaspora: Community-building on the Indian Ocean rim (New York: Berghahn Books, 2010); Y.A. Talib, "Studies on the South Arabian diaspora: Some critical remarks," Diogenes, 28, 11 (1980), 35-49; Iain Walker, "The Hadrami diaspora," in The Routledge Handbook on Middle Eastern Diasporas, eds. Dalia Abdelhady and Ramy Aly (London, New York: Routledge, forthcoming).
} 
possibilities, coax people back; people return for affective reasons, or out of a sense of obligation, to kin or to themselves; and sometimes people are "forced" to return, as during the wave of anti-Arab sentiment felt in parts of East Africa during the 1960s. ${ }^{3}$

In what follows I use the Hadrami diaspora as a case study in an exploration of the very concept of "diaspora." This material is based on my research in the western Indian Ocean - my ethnography does not permit me to extend my discussion to the Hadrami diaspora in South or Southeast Asia, but it should not be understood that there are no links with the latter places. Before engaging with the ethnography, however, allow me to begin with some thoughts on the notion of diaspora itself, considering in particular whether it continues to have purchase as an analytical tool.

\section{A DiAsPora, BUt FOR WHOM - AND FOR WHAT?}

Over the past three decades, the use of the word diaspora has seen remarkable growth, both within academia and in popular discourse, and there are now three relatively distinct, if interrelated fields within which the term is employed. The first is the vernacular, in which "diaspora" appears to refer to almost any group of expatriates, or even to expatriates who do not form a group. This use of the word need not concern us here, even if it has elements in common with other uses. The second use of the term is political. The significant growth of global migratory flows has been accompanied by a recognition, particularly (but not exclusively: roots tourism is of some economic significance to countries such as Ireland) in less developed countries, that emigrant populations living in more developed countries are a valuable resource in terms of the potential for contributions to the economy, both by those who remit and by those with skills lacking in

\footnotetext{
${ }^{3}$ Ulrike Freitag, Indian Ocean Migrants and State Formation in Hadhramaut. Reforming the homeland (Leiden: Brill, 2003); Engseng Ho, The Graves of Tarim: Genealogy and mobility across the Indian Ocean (Berkeley: University of California Press, 2006); Engseng Ho, "Hadhramis abroad in Hadhramaut: The Muwalladin," in Hadhrami Traders, eds. Freitag and Clarence-Smith, 131-46; Leif Manger, "Negotiating the homeland: Diasporic consciousness and social stratification among Hadramis in the Indian Ocean region," in Contested Memories and the Demands of the Past: Islam and nationalism, ed. Catharina Raudvere (Cham, CH: Palgrave Macmillan, 2017), 49-80; Thomas Pritzkat, Stadtentwicklung und Migration im Südjemen: Mukalla und die hadhramitische Auslandsgemeinschaft (Wiesbaden: Dr. Ludwig Reichert Verlag, 2001); Alessandra Vianello, "One hundred years in Brava: The migration of the 'Umar Bā "Umar from Hadhramaut to East Africa and back, c.1890-1990," Journal of Eastern African Studies, 6, 4 (2012), 655-71; Iain Walker, "From Moroni to Mukalla: Hadhramis on the Island of Ngazidja (Comoros) and in the Hadhramhout," Journal des Africanistes, 72, 2 (2002), 111-22; Iain Walker, "Hadramis, shimalis and muwalladin: Negotiating cosmopolitan identities between the Swahili coast and southern Yemen," Journal of Eastern African Studies, 2, 1 (2008), 44-59; Iain Walker, "Hybridity, belonging, and mobilities: The intercontinental peripatetics of a transnational community," Population, Space and Place, 17, 2 (2011), 167-178; Iain Walker, "Comorians and Hadramis in the western Indian Ocean: Diasporic practices in a comparative context," Social Dynamics, 38, 3 (2012), 435-53; Iain Walker, "Hadrami identities in Saudi Arabia," in Rebuilding Yemen: political, economic and social challenges, eds. Noel Brehony and Saud al Sarhan (Berlin: Gerlach Books, 2015), 42-60.
} 
the homeland who might be persuaded to return. Recognising these communities and fostering a sense of self-awareness among them as a distinct group with a distinct, national, identity is an essential strategy in maintaining their engagement with, and hence the development of, the homeland. The term "diaspora" is increasingly applied to these emigrants, by NGOs, policymakers, analysts and others, and the number of diaspora institutions across the world has grown commensurately. ${ }^{4}$ These diasporans are generally found in a variety of geographical locations and are constituted as a coherent but spatially dispersed group of groups by virtue of their relationships with the state that controls their homeland. However, whether these different constituent groups maintain relationships with each other is another matter.

This political usage of the term diaspora can be distinguished conceptually from a third usage, the analytical concept that is invoked in migration studies and in academia more widely. There is no need here to retrace the history of the concept, nor the way that, even in academia, its meaning "has been stretched in various directions," as Brubaker politely puts it. ${ }^{5}$ As early as 1991 , William Safran was drawing attention to the way the term was being stretched, and since then numerous scholars have taken up the theme, noting the proliferation of texts referring to diaspora(s) and the accompanying slackening of definition: this ground has been well trodden, and those who have paid the critics no heed will not do so now. ${ }^{6}$ However, and although some scholars have suggested

\footnotetext{
${ }^{4}$ See: Alexandra Delano Alonso and Harris Mylonas, "The Microfoundations of diaspora politics: Unpacking the state and disaggregating the diaspora," Journal of Ethnic And Migration Studies, 45, 4 (2019), 473-91; Alan Gamlen, "Diaspora institutions and diaspora governance," International Migration Review, 48, Supplement 1 (2014), S180-S217; Alan Gamlen, Michael E. Cummings, and Paul M. Vaaler, "Explaining the rise of diaspora institutions," Journal of Ethnic and Migration Studies, 45, 4 (2019), 492-516; Bahar Baser Ozturk and Henio Hoyo "Introduction to the special issue: Politics, policies and diplomacy of diaspora governance: New directions in theory and research," Migration Letters, 17, 1 (2020), 1-6.

${ }^{5}$ Rogers Brubaker, "The 'diaspora' diaspora," Ethnic and Racial Studies, 28, 1 (2005), 1. See also: Martin Sökefeld, "Mobilizing in transnational space: A social movement approach to the formation of diaspora," Global Networks, 6, 3 (2006), 265-84. For a thorough survey history of the word, diaspora, see: Stéphane Dufoix, The Dispersion: A history of the word diaspora (Leiden: Brill, 2016).

${ }^{6}$ William Safran, "Diasporas in modern societies: Myths of homeland and return," Diaspora, 1, 1 (1991), 83-99; Khachig Tölölyan, "Diasporama," Diaspora, 3, 2 (1994), 235; Khachig Tölölyan, "Rethinking diaspora(s): Stateless power in the transnational moment," Diaspora, 5, 1 (1996), 3-36; Khachig Tölölyan, "Diasporama," Diaspora, 9, 2 (2000), 309-310; Floya Anthias, "Evaluating 'diaspora': Beyond ethnicity?" Sociology, 32, 3 (1998), 557-80; Thomas Faist, "Diaspora and transnationalism: What kind of dance partners?" in Diaspora and Transnationalism: Concepts, theories and methods, eds. Rainer Bauböck and Thomas Faist (Amsterdam: Amsterdam University Press, 2010), 9-34; Rogers Brubaker, "Revisiting 'The "diaspora" diaspora'," Ethnic and Racial Studies, 40, 9 (2017), 1556-61. According to Web of Science, in 1990 there were barely a dozen articles with the word "diaspora" in the title; in 2019 there were almost 600. Most of these texts appear to refer to migrants, or immigrants, rather than diasporas, although of course (sic) I have not read them all. Google Ngram Viewer confirms the pattern. See also works by Alexander and Dufoix on the exponential growth in the use of the term since the 1990s (Claire Alexander, "Beyond 'the 'diaspora' diaspora': a response to Rogers Brubaker," Ethnic and Racial Studies, 40, 9 (2017), 1544-55; Dufoix, The Dispersion).
} 
abandoning the term, ${ }^{7}$ I believe there remains something to be salvaged in the concept that allows us to employ it usefully, in an analysis of a particular type of population that is spatially dispersed. While I do not wish to revisit the (multiple) definitions of diaspora William Safran's 1991 six point definition is much cited, likewise Robin Cohen's 2008 development of it, and some continue to attempt to pin the word down - I would like to draw out its salient features, and particularly those that allow the term to serve us usefully rather than, as appears to be current practice, as just a gloss for "a group of migrants."

I suggest that rather than defining what a diaspora is we instead pay attention to what it does. ${ }^{9}$ More than just a group of migrants, a diaspora enjoys some degree of social cohesion that brings together the different localisations of the diaspora into a network whose members recognise their commonalities and which extends through both space and time. Thus not only is a diaspora "a transnationally dispersed collectivity that distinguishes itself by clear self-imaginations as community," but one whose members work (whether actively or passively) to maintain its status as a collectivity, and for whom the fact of constituting a collectivity is instrumental. ${ }^{10}$ This sort of definition rapidly excludes the vast majority of "diasporas" that, first (and despite repeated warnings about methodological nationalism), are often built on nothing more cohesive than a common passport and, second, do not have any real sense of community across their multiple localisations. ${ }^{11}$ Certainly, some will be bound by kin ties, or share origins in the same village, but this is not sufficient to constitute a diaspora. What is required is "a strong ethnic group consciousness sustained over a long time and based on a sense of

\footnotetext{
${ }^{7}$ See, for example: Yasemin Nuhğolu Soysal, "Citizenship and identity: Living in diasporas in post-war Europe?" Ethnic \& Racial Studies, 23, 1 (2000), 1-15.

${ }^{8}$ Safran, "Diasporas in modern societies," 83-99; Robin Cohen, Global Diasporas: An Introduction (Abingdon: Routledge, 2008). For a more recent attempt at definition, see: Jonathan Grossman, "Toward a definition of diaspora," Ethnic and Racial Studies, 42, 8 (2019): 1263-82.

${ }^{9}$ This point has been made several times, such as in: Brubaker "The 'diaspora' diaspora," 1-19.

${ }^{10}$ Sökefield, "Mobilizing in transnational space," 267. Interestingly, although Sökefeld's article has been widely cited, most citing authors seem to have missed the point, ignoring his suggestion that diaspora exhibit "clear self-imaginations as community." See also: Ghassan Hage's characterisation of the Lebanese diaspora as a "single geographically discontinuous site" (Ghassan Hage, "A not so multi-sited ethnography of a not so imagined community," Anthropological Theory, 5, 4 (2005), 463). These themes are furthermore addressed in the introduction to this special issue: Iain Walker and Martin Slama, "The Indian Ocean as a diasporic space: A conceptual introduction," Journal of Indian Ocean World Studies, 4, 2 (2021), 2-16.

${ }^{11}$ See, for example: Nina Glick Schiller, A Global perspective on Transnational Migration: Theorizing migration without methodological nationalism (Working Paper No. 67, Centre on Migration, Policy and Society University of Oxford, 2009); Alex Sager "Methodological nationalism, migration and political theory," Political Studies, 64, 1 (2016), 42-59; George Vasilev, "Methodological nationalism and the politics of history-writing: how imaginary scholarship perpetuates the nation," Nations and Nationalism, 25, 2 (2019), 499-522; Andreas Wimmer and Nina Glick Schiller, "Methodological nationalism, the social sciences, and the study of migration: an essay in historical epistemology," The International Migration Review, 37, 3 (2003), 576-610.
} 
distinctiveness [... and] a sense of empathy and co-responsibility with co-ethnic members in other countries of settlement." 12 This provides for a practical, enacted cohesion as a diaspora; and this seems key to distinguishing a diaspora from other migrant communities.

Two elements seem essential for the establishment of this cohesion. The first is to insist upon the temporal depth of diasporas. A diaspora is constituted over more than one generation, if not for each member of the diaspora (since the nature of a diaspora is precisely that people may use their diasporic belonging to move), then for the majority, and certainly for the diaspora itself. While we can accept that most migrants are potentially diasporic, the emphasis is upon "potentially": this seems to me to be crucial. It is not only understandable but expected that migrants retain ties with both their homeland and/or with other emigrants of their own community (however that might be defined) since they may not speak the language of the host country nor (yet) be socially integrated, and may even intend to go home, once they have enough money, or, perhaps, when the war is over. However, the fact of migration is not sufficient to constitute a diaspora: a diaspora only comes into existence beyond the migratory movements that created it precisely because a degree of immobility is required for a diaspora to consolidate itself. Diasporas are characterised by perennity. If migrants are assimilated in the next generation, they are not a diaspora. ${ }^{13}$ It is only when a diasporic collectivity has established an enduring social cohesiveness - not just cultural: it is easy but largely symbolic to demonstrate Irishness by singing along to the Pogues over a pint of Guinness on St Patrick's Day - that extends into subsequent, locally-born generations that we can truly speak of a diaspora, even if this social cohesiveness is fluid and contingent. ${ }^{14}$ The diaspora is historically constituted and through its historicity shapes contemporary practice - what Avtar Brah called "diachronic relationality." 15 The historical and the contemporary coalesce in diaspora. Iraqis or Somalis may be dispersed as a result of conflict in their homelands, and might well be "incipient diasporas," but I am circumspect about the possibility of their already

\footnotetext{
12 Cohen, Global Diasporas, 17.

${ }^{13}$ See also: Brubaker, "The 'diaspora' diaspora," 1-19.

${ }^{14}$ For the St. Patrick's Day example, see: John Nagle, "Everybody is Irish on St. Paddys: Ambivalence and alterity at London's St. Patrick's Day 2002,” Identities - Global Studies in Culture and Power, 12, 4 (2005), 563-83.

15 Avtar Brah, Cartographies of Diaspora: Contesting identities (London: Routledge, 1996), 197 [Emphasis in the original]. Likewise Nicholas Van Hear's statement: "Diasporas need to endure before being considered as such" (Nicholas Van Hear, "Migration," in Diasporas: Concepts, intersections, identities, eds. Kim Knott and Seán MacLoughlin (London: Zed Books, 2010), 37), and Robin Cohen's, “sustained over a long time" (Cohen, Global Diasporas, 17 (cited above)).
} 
constituting a diaspora - and as opposed to joining an already-existing diaspora, as, for example, Iraqis might do. ${ }^{16}$

This brings us to the second characteristic of the diaspora: diasporas are not about migrants, indeed often quite the opposite. ${ }^{17}$ Diasporas are characterised by real immobility and imagined mobility. Many members of diaspora have never moved, at least not very far or for very long, and are quite firmly embedded where they are: they belong. ${ }^{18}$ Integrated but not assimilated, they are locals, not (im)migrants, members of society in the places where they live. We therefore need to dissociate diaspora and migration, at least insofar as the analysis of diasporic identity is concerned. This does not mean that that diasporas are not defined by migration - they clearly are - but that migration is not necessarily part of diasporic practice. A diaspora has much in common with a community that is not spatially dispersed: it includes all members of the group wherever they are found, as well as, in many important respects, people in the homeland. The homeland is important because it provides a framework for diasporic practice, a point of reference that establishes parameters and points of reference for those things that diasporans do. But the homeland can be, and often is imagined. A desire to return is not necessary, and many diasporans would not want to return. Many, probably most, diasporans are as fixed as "natives": locally born, they are natives. ${ }^{19}$

\section{A "Diaspora FOR OTHERs"}

Temporal depth and a certain immobility provide clues as to the diasporic form. However, if we accept, as I have proposed above, that the salience of the concept of the diaspora lies its instrumentality, then we clearly need to ask how and where diasporic identities are called into play. Citing primarily from examples related to the Hadrami diaspora in the western Indian Ocean, there are four fields within which diaspora practices occur:

\footnotetext{
${ }^{16}$ Myron Weiner, "Labor migrations as incipient diasporas," in Modern Diasporas in International Politics, ed. Gabriel Sheffer (London: Croom Helm, 1986), 47-74; Farah Ali, "Where should the birds fly after the last sky? Images and voices of women of the Iraqi diaspora in the United Kingdom," Diaspora Studies, 11, 2 (2018), 135-51; Neil Carrier and Emma Lochery, "Missing states? Somali trade networks and the Eastleigh transformation," Journal of Eastern African Studies, 7, 2 (2013), 334-52; Zainab Saleh, "'Toppling' Saddam Hussein in London: Media, meaning, and the construction of an Iraqi diasporic community," American Anthropologist, 120, 3 (2018), 512-22.

${ }^{17}$ See: Paul Tabar, "Transnational is not diasporic: A Bourdieusian approach to the study of modern diaspora," Journal of Sociology, 56, 3 (2020), 455-71.

${ }^{18}$ Claire Alexander, Joya Chatterji, and Annu Jalais, The Bengal Diaspora: Rethinking Muslim migration (Abingdon: Routledge, 2015).

${ }^{19}$ See also, for example: Irina Kudenko and Deborah Phillips, "The Model of integration? Social and spatial transformations in the Leeds Jewish community," Journal of Ethnic and Migration Studies, 35, 9 (2009), 1533-49; Uzi Rebhun, "Jewish identification in contemporary America: Gans's symbolic ethnicity and religiosity theory revisited," Social Compass, 51, 3 (2004), 349-66.
} 
1. Intra-diasporic refers to social and cultural practices within a specific diasporic localisation, the sorts of practices engaged by locally resident members of a diaspora, how they express, perform, maintain and renew their identities, the sorts of relationships they maintain with each other, including but not limited to the links of kinship. Thus, for example, Hadramis in Ngazidja may marry one another, do business together, join the same sufi tariqa and attend the same religious events. ${ }^{20}$ These strategies reinforce local diasporic identities.

2.Trans-diasporic refers to the relationships between different diasporic localisations (for example, Hadramis in Zanzibar and Hadramis in Abu Dhabi), how they interact with one another, and how their diasporic practices and expressions of identity are both constructed by and shape their interactions. This may be manifested through kin links, economic ties, political and religious networks, all of which may facilitate movement or contribute to the maintenance of diasporic identities. In these contexts, diasporic strategies are generally aimed at downplaying differences - and differences there often are - and stressing shared values.

3. Homeland-diasporic refers to the relationships between the diaspora and the homeland. These practises and strategies will further be shaped by the diasporic localisation and, again, by political and economic contexts and religious and kin links. So, people may return to Hadramawt to marry, to visit, to do business, or to retire. There is often a tension in these relationships: diasporans may return home to find that they are not "at home" there after all. Nevertheless, these links also contribute to the construction of a particular Hadrami identity that may then be carried into, or returned to, diaspora.

4. Hostland-diasporic refers to the relationships between the diaspora and the "host" community, that is, with other people where they live. This may include the adoption of practices that run counter to Hadrami practice, such

\footnotetext{
${ }^{20}$ For Hadramis in Ngazidja, see: Walker, "From Moroni to Mukalla," 111-22; Iain Walker, Becoming the Other, Being Oneself: Constructing identities in a connected world (Newcastle: Cambridge Scholars Publishing, 2010); Walker, "Comorians and Hadramis," 435-53.
} 
as the matrilineal systems of inheritance and uxorilocal residence rules in Ngazidja; but there may also be attempts to shape local practice to conform to Hadrami expectations, such as the partial withdrawal of the sada, descendants of the Prophet, from certain ritual practices in Ngazidja. The negotiation of these differences, often characterised by a certain tension, can either reinforce a sense of identity among diasporans, or lead to assimilation and ultimately a loss of diasporic identity. In exceptional cases, they may see the host society becoming more "diasporic". ${ }^{21}$

The interplay between the practices and the strategies engaged in these different fields and in these different spaces, both social and physical, depends upon and produces contingent identities and differential ways of belonging across the diaspora, and interactions in all four fields are a necessary pre-condition for the constitution of a diaspora.

One final theoretical move involves a decentring of the homeland. ${ }^{22}$ Clearly, the homeland has both practical and symbolic significance for diasporans. It is a qualitatively different place for diasporans and, both practically and in the popular imagination, remains crucial to constructions of diasporans' sense of identity. ${ }^{23}$ The homeland may be distinguished from other places on diasporans' trajectories by the fact that a relationship always potentially exists between diasporans and the homeland - people of Hadrami origins may "return" to Hadramawt after several generations in the diaspora and "reclaim" their Hadrami identities (and, in many cases, their Yemeni citizenship) - that does not exist with other places, even when formal advantages such as (for example) rights to citizenship have expired. ${ }^{24}$ Nevertheless, and particularly for those who have no real knowledge of it, for practical purposes, the homeland is just another place on diasporic (social) trajectories, not really very different, given the potential of networks, from other

\footnotetext{
${ }^{21}$ Sada in East Africa are almost all of Hadrami origin. For more on the sada in Ngazidja and the Hadrami character of Ngazidja society, see: Walker, Becoming the Other.

${ }^{22}$ The notions and roles of "home" and "homeland" have been competently explored in some edited collections, for example: Nigel Rapport and Andrew Dawson (eds.), Migrants of Identity: Perceptions of home in a world of movement (Oxford: Berg, 1998); Lynellyn D. Long, and Ellen Oxfeld, (eds.), Coming Home? Refugees, migrants, and those who stayed behind (Philadelphia: University of Pennsylvania Press, 2004); and: Fran Markowitz and Anders Stefansson (eds.) Homecomings: Unsettling paths of return (Lanham: Lexington Books, 2004); as well as more recently in a monograph: Shelly Chan, Diaspora's Homeland: Modern China in the age of global migration (Durham: Duke University Press, 2018). ${ }^{23}$ See, for example: Laura Jeffery, "How a plantation became paradise: Changing representations of the homeland among displaced Chagos islanders," Journal of the Royal Anthropological Institute, 13, 4 (2007), 951-68; Paul Tabar, "The Lebanese diasporic field: The impact of sending and receiving states," Immigrants and Minorities, 34, 3 (2016), 256-75.

${ }^{24}$ Takeyuki, Tsuda (ed.), Diasporic Homecomings: Ethnic return migration in comparative perspective (Stanford: Stanford University Press, 2009).
} 
diasporic locations. While not denying its symbolic importance, therefore, decentring the homeland allows us to re-place it as a diasporic location amongst others. ${ }^{25}$

The identification of four fields within which diasporic practices are played out, coupled with a decentring of the homeland and the recognition that diasporans are often quite at home at the places in which they live, necessarily calls for a re-centring of the concept of diaspora itself. ${ }^{26}$ In his discussion of transnational allegiances and diasporic commitment, Nicholas Van Hear observed that while some diasporas are active, socially, culturally or politically, as diasporas, others do little to engage their diasporic identities, sometimes even failing to acknowledge them at all, at least until such time as they become useful or relevant. "Paraphrasing Marx," he suggests "that where diasporas are dormant, latent or avoided, diaspora exists 'in itself', and where diasporas are actively maintained and where migrants actively engage in them, diaspora exists "for itself"."27 However, while this distinction may be useful, it does not distinguish diasporas based on how they are, merely on what they are, and I would therefore propose extending Van Hear's distinction (perhaps drawing on Sartre in addition to Marx) by invoking a third category, of the existential diaspora, if you like, a "diaspora for others." 28 A "diaspora for others" is a diaspora that includes most, if not all members of a particular group - an ethnic group, perhaps - living outside the homeland, who subscribe to a common identity, however that identity may be constructed, and whose different spatially dispersed parts are linked to each other, both practically and symbolically, as well as (except where not possible) to the homeland. ${ }^{29} \mathrm{~A}$ "diaspora for others" only endures - and endure it must in order to remain a diaspora - if the social conditions of the different localisations of the diaspora and the links between them provide potential for action for all diasporans, actions that subsequently reaffirm and reinforce these actors' diasporic being, as members of a

\footnotetext{
${ }^{25}$ See also: Alexander, Chatterji, and Jalais, The Bengal Diaspora; Alexander, "Beyond 'the 'diaspora' diaspora'," 1544-55. ${ }^{26}$ See, for example: Ien Ang, "Beyond Chinese groupism: Chinese Australians between assimilation, multiculturalism and diaspora," Ethnic and Racial Studies, 37, 7 (2014), 1184-96; Jennifer M. Brinkerhoff, "Assimilation and heritage identity: Lessons from the Coptic diaspora," Journal of International Migration and Integration, 17, 2 (2016), 467-85; Nina Glick Schiller, "Diasporic cosmopolitanism: Migrants, sociabilities and city making," in Whose Cosmopolitanism? Critical perspectives, relationalities and discontents, eds. Nina Glick Schiller \& Andrew Irving (New York; Oxford: Berghahn, 2015), 103-20; Pam Papadelos, “"Greeks are different to Australians': Understanding identity formation among thirdgeneration Australians of Greek heritage," Ethnic and Racial Studies (forthcoming; published online: 7 September 2020; DOI: 10.1080/01419870.2020.1813318).

${ }^{27}$ Nicholas Van Hear, New Diasporas: The mass exodus, dispersal and regrouping of migrant communities (London: UCL Press, 1998), 250.

${ }^{28}$ Jean-Paul Sartre, L'être et le Néant: essai d'ontologie phénoménologique (Paris: Gallimard, 1943).

${ }^{29}$ See also: Eliezer Ben-Rafael, "Diaspora,” Current Sociology, 61, 5-6 (2013), 842-61.
} 
community ("Hadramis," for example) with shared understandings and interests that cohere in both time and space..$^{30}$

The enduring character of a diaspora must be based on principles of belonging that are not only susceptible but likely to be transmitted intergenerationally, providing for diasporic reproduction, such as language, membership of a lineage, or religion; and we indeed see that "diasporas for others" are bound by one or more of these criteria. So, the Hadrami diaspora is constructed, or constructs itself, about a network of relationships in several fields (in the Bourdieusian sense) of interaction: religion and sufi practices, for example, or tribal identity, or trading networks. These fields, and people in different places, all intersect in different ways to produce Hadrami-ness, and, all while remaining Hadrami, sharing a sense of identity (partly, at least, imagined), identarian strategies are nevertheless locally specific. There are Hadramis who are Hijazis, Zanzibaris, Khalijis or Wangazidja; ${ }^{31}$ Saudis, Tanzanians, Emiratis or French. There are Hadramis who are Yemenis, and of course there are Hadramis who are Hadramis (sic). Metaphors often used include overlapping, intersecting or even multiple, ${ }^{32}$ but this sort of terminology suggests distinct identities that neither meet not merge but somehow co-exist, linked, possibly, but in parallel. I would prefer to view these identities as interwoven, since their boundaries are often fluid, and the identities that emerge from and produce both practices and imaginaries sometimes meet in surprising ways.

\section{Al MAHJAR AL HADRAMI}

If the very word diaspora was first invoked in the Septuagint to describe the Jewish community in exile, then the Hadrami diaspora is similarly characterised by a specific term, the mahjar. ${ }^{33}$ The Arabic word mahjar is derived from the same root as Hegira, the exile of the Prophet Muhammad to Medina, but the prefix, $m a$ - is a locative one: the word mahjar therefore refers to an emplaced exile, a diaspora. ${ }^{34}$ This is a very different word,

\footnotetext{
${ }^{30}$ Walker and Slama, "The Indian Ocean as diasporic space," 2-16.

${ }^{31}$ Khalijis are Arabs from the coasts of the Persian Gulf; Wangazidja are the people of Ngazidja.

${ }^{32}$ See, for example: Rainer Baubock, "Genuine links and useful passports: Evaluating strategic uses of citizenship," Journal of Ethnic and Migration Studies, 45, 6 (2019), 1015-26; Andrea Schlenker, Joachim Blatter, and Ieva Birka, "Practising transnational citizenship: Dual nationality and simultaneous political involvement among emigrants, "Journal of Ethnic and Migration Studies, 43, 3 (2017), 418-40; Pnina Werbner, "Everyday multiculturalism: Theorising the difference between 'intersectionality' and 'multiple identities'," Ethnicities, 13, 4 (2013), 401-19.

${ }^{33}$ See: Dufoix, The Dispersion; and, for the history of the word "diaspora," see also: Martin Slama and Johann Heiss, "Comparing Arab diasporas: Post-9/11 and historical perspectives on Hadhrami and Syro-Lebanese communities in Southeast Asia and the Americas," Comparative Studies of South Asia, Africa and the Middle East, 31, 2 (2011), 231-50.

${ }^{34}$ Walker, "Hadrami identities," 46.
} 
and concept, from that which is applied to other diasporas, such as the Palestinian and the Lebanese, whose diasporas are described as al shatat, from the verb shatta, to be dispersed or scattered: neither exiled nor emplaced. Hadramis are well aware of their diasporic condition, aware that they are members of a community that is both spatially dispersed and locally embedded. In what follows, using Hadramis as a case study, I develop the idea of a "diaspora for others" by weaving together a selection of biographical narratives that take us on a journey, or a number of journeys, through the western Indian Ocean region: through a part of the Hadrami diaspora, following people who are both dispersed and embedded. As we shall see, these narratives both emerge from and constitute the framework for Hadrami diasporic practices, exemplifying the four fields of diasporic practices that I have identified above. ${ }^{35}$

\section{Ngazidja}

Hadramis constitute a small but socially significant minority on the Comorian island of Ngazidja. Almost all are sada, both cause and effect of the island's reputation for religious learning. The most prominent lineages are the Jamal al Lail, from Tarim, and the Abubakar bin Salim, from Inat. Nevertheless, there are families from other social strata, such as the Bashrahail, qabail from Ghail Ba Wazir; the Bin Bobah, a mashaykh tribe; and the Wadaane, masikin from Shibam. The first Wadaane to arrive in Ngazidja was Abdallah bin Awadh, whose father was a businessman in Zanzibar. Abdallah, knowing that there were Hadramis in Ngazidja, came to the island at the beginning of the twentieth century, established a business trading with Zanzibar and Hadramawt, and married a local

\footnotetext{
${ }^{35}$ On Hadramis in the western Indian Ocean region, see, for example and in addition to texts cited above: Abdullah Mohammed Alajmi, "In the House, Around the House: An ethnography of Hadar Hadrami migration to Kuwait" (Unpublished PhD diss., London School of Economics, 2007); Anne K. Bang, Sufis and Scholars of the Sea. Family networks in East Africa, 1860-1925 (London: Routledge Curzon 2003); Anne K. Bang, Islamic Sufi Networks in the Western Indian Ocean (c. 1880-1940): Ripples of reform (Leiden: Brill, 2014); Anne K. Bang, "Hadramis in Africa," in Oxford Research Encyclopedia of Asian History (2019) [DOI: 10.1093/acrefore/9780190277727.013.324; accessed: 23 March 2021]; Samson Bezabeh, "Yemeni families in the early history of Addis Ababa, Ethiopia ca.1900-1950: A revisionist approach in diasporic historiography," Cahiers d'Études africaines, 51, 4 (2011), 893-19; Michael Field, The Merchants: The big business families of Saudi Arabia and the Gulf states (Woodstock: Overlook Press, 1985); Françoise Le GuennecCoppens, "Les masharifu Jamalilil à Lamu," Annuaire des Pays de l'Océan Indien, 6 (1979), 91-102; Françoise Le Guennec-Coppens, "Social and cultural integration: A case study of the East African Hadramis," Africa, 59, 2 (1989), 18595; Françoise Le Guennec-Coppens, "Qui épouse-t-on chez les Hadrami d'Afrique orientale. Les réseaux d'alliances," in Les Swahili entre Afrique et Arabie, eds. Françoise Le Guennec-Coppens and Pat Caplan (Paris: Karthala, 1991), 145-62; B. G. Martin, "Arab migrations to East Africa in medieval times," The International Journal of African Historical Studies, 7, 3 (1974), 367-390; Jonathan Miran, "Red Sea translocals: Hadrami migration, entrepreneurship, and strategies of integration in Eritrea, 1840s-1970s," Northeast African Studies, 12, 1 (2012), 129-167; Anushyama Mukherjee, "Idea of homeland/s: Hadramis of Barkas in the Persian Gulf," in Shifting Transnational Bonding in Indian Diaspora, ed. R. Gowricharn (London: Routledge 2020), 197-210; Philippe Pétriat, Le Négoce des Lieux Saints: Négociants hadramis de Djedda, 18501950 (Paris : Publications de la Sorbonne, 2016).
} 
woman of Hadrami origin, thereby founding a family whose members today own a variety of local businesses. Over the years the Wadaanes have maintained their links with the family in Shibam, where, deeming their daughters to be of too low status to marry Comorian sada, they continue to seek husbands among kin, thus maintaining the circulation of people between the two places. ${ }^{36}$ Likewise, Abdulqadr Obeid Al Malahi, born in Shihr, was sent by the Bashrahail family, for whom he worked, to manage their office in Zanzibar, later moving to Ngazidja where he eventually went into business with another family from Ghail Ba Wazir, the Al Haj. He took over the Comorian end of the business, trading vanilla, wood, coconuts and perfume oils, and married a Comorian-born woman of Omani origin. The family moved between between Hadramawt and Ngazidja for much of the first part of the twentieth century, both for business reasons and, as one of the family explained, to "regain their culture and their tradition." Abdulqadr's son Ali, born in the Comoros but who spent most of his childhood in Hadramawt, married an Indonesian-born woman of Hadrami origin and returned to Moroni; following her death he left Ngazidja for good, moving to Dar es Salaam and then, after Tanzanian independence in the 1960s, "home" to Shihr to retire. The family in Shihr still maintains contact with associates in Ngazidja, even if this is largely in an attempt to regain property left behind in the 1960s. These are just a few examples of how Comorians of Hadrami origin maintain their links with other Hadramis, and with Hadramawt, employing strategies that are both trans-diasporic and homeland-diasporic.

However, Hadramis also belong locally: they have been present in the Comoros for centuries, indeed, probably as long as any of the other immigrant populations that have constituted the island's population. ${ }^{37}$ Unsurprisingly, therefore, many who claim a Hadrami identity are not particularly mobile, retaining perhaps only a family tradition or the name of their tribe or lineage, and their relationships with others locally are clearly both intra-diasporic and hostland-diasporic. Since Hadrami women rarely emigrated, Hadramis invariably ended up marrying local women, preferably but not always of Hadrami origin themselves. Ngazidja is a matrilineal society and residence after marriage is uxorilocal: this rendered it relatively simple for high status Hadrami migrants to marry into high status local matriclans and be sure of a home and status. Subsequently,

\footnotetext{
${ }^{36}$ Hierarchies within Hadrami communities are marked by the sada-non-sada divide, although in locally specific ways. See, for example: Manger, "Negotiating the homeland," 49-80. And specifically on the most significant manifestation of this division, the Alawi-Irshad conflict in Indonesia: Nathalie Mobini-Kesheh, The Hadrami Awakening: Community and identity in the Netherlands East Indies, 1900-1942 (Ithaca: Cornell SEAP Publications, 1999); Martin Slama "Marriage as crisis: revisiting a major dispute among Hadhramis in Indonesia," Cambridge Anthropology, 32, 2 (2014), 65-80.

${ }^{37}$ Iain Walker, Islands in a Cosmopolitan Sea: A history of the Comoros (London: Hurst \& Co., 2019).
} 
membership of both matriclan and Hadrami patrilineage could be passed on to children in what is effectively a dual descent system; and if children might otherwise be liable to pass out of these lineages, the different marriage preferences - patrilateral parallel cousin for the Hadramis and matrilateral cross-cousin for the Wangazidja - generally converge to provide membership of both lineages to all children. A more efficient way of diasporic belonging is hard to imagine. ${ }^{38}$

Said Ahmed bin Sumeit, chief cadi of Zanzibar in the early twentieth century, and his son Said Omar, the first Grand Mufti of the Comoros, were perhaps the most illustrious of the island's sons. Members of the Bin Sumeit sada lineage of Shibam, both were born in Ngazidja but educated in Zanzibar as well as in Hadramawt; both travelled widely, Ahmed following kin links as far as Java while his son spent ten years in Madagascar. ${ }^{39}$ Their descendants today, following the family tradition, perhaps, live in a variety of locations, from Ngazidja and Zanzibar to Abu Dhabi, Dubai, and beyond, and regularly visit Hadramawt itself. These sorts of movements are made possible by kinship, but also by the existence of Hadrami scholarly networks, dominated by the sada and within which Ngazidja is but one of many nodes. ${ }^{40}$ Scholars from Hadramawt regularly visit the island and local scholars, like Ahmed and Omar, either studied or taught (or both) in Zanzibar, Lamu, Cairo or Hadramawt itself. ${ }^{41}$ By the same token, religious events bring people together. Mohammed Ahmed Djelane, the late cadi of Moroni and a member of the Abubakar bin Salim sada lineage, met Said Hassan al Hadad, the mufti of Inat, at the hauli, commemoration of the life, of Said Omar bin Sumeit, in the town of Itsandramdjini on Ngazidja. They struck up a friendship and Mohammed's guest subsequently invited him back to Hadramawt - his first visit to the homeland - where he spent a month, amongst other things visiting ancestral graves.

\footnotetext{
${ }^{38}$ Walker, "From Moroni to Mukalla," 111-22.

${ }^{39}$ Bang, Sufis and Scholars; Anne K. Bang, "My generation. Umar b. Ahmad b. Sumayt (1886-1973): Inter-generational network transmission in a trans-oceanic Hadrami Alawi family, ca. 1925-1973," in Diasporas Within and Without Africa: Dynamism, hetereogeneity, variation, eds. L. Manger \& M. Assal (Uppsala: Nordic Africa Institute, 2006), 87-103.

${ }^{40}$ Bang, Sufis and Scholars; Bang, Islamic Sufi Networks.

${ }^{41}$ A. A. Ahmed, "The Impact of Hadrami scholarship in Kenyan Islam," in Islam in Kenya. Proceedings of the National Seminar on Contemporary Islam in Kenya, eds. Mohamed Bakari and Saad S. Yahya, (Nairobi: Mewa Publications, 1995) 158-67; Abdallah Chanfi Ahmed, Ngoma et mission islamique (da'wa) aux Comores et en Afrique orientale (Paris: L'Harmattan, 2002); Abdalla al-Farsy, Tarehe ya Imam Shafi na Wanyavyuoni wakubwa wa Mashariki ya Afrika (Zanzibar: Zanzibar Education Dept., 1944); Toibibou Ali Mohamed, La Transmission de l'Islam aux Comores (1933-2000) (Paris: L'Harmattan 2008); al-Junayd, Abd al-Qadir b. Abd al-Rahman b. Umar, Al- 'Uqūd al-Jāhiza wa al-wu'üd al-Nājiza. Fi tarājim ba'ḍ al-shakhșiyāt al-bāriza (India: printed for the author, n.d.); Bang, Sufis and Scholars; Bang, Islamic Sufi Networks; B. G. Martin, "Notes on some members of the learned classes of Zanzibar and East Africa in the nineteenth century," African Historical Studies, 4, 3 (1971), 525-45.
} 
The hauli of Said Omar is just one of many events that attracts people from all over the region and from further afield, and the networks that these religious links create provide pathways through which people move. Another Ngazidja Hadrami who drew on them was Habib Swaleh b. Alawi Jamal al Lail. Born in Ntsudjini, he moved to Lamu as a young man and in 1889 founded the town's Riyadha Mosque. ${ }^{42}$ Aimed particularly at the ordinary people of the coast, the mosque rapidly became a centre for learning, drawing students and scholars from across the region.

\section{Lamu}

One of the principal events in the Islamic calendar is Maulid, the celebration of the birthday of the Prophet, and one of the most popular Maulids in East Africa is organised by the Riyadha Mosque. The Lamu Maulid was established in 1909 when a new maulidi - a religious text in praise of the Prophet - was composed by the scholar Ali b. Muhammad al Habshi in Seiyun, Hadramawt. This was the Simt al Durar, "string of pearls," more musical than the other maulidi in use at the time and intended to have widespread appeal. ${ }^{43}$ The contemporary Lamu Maulid has its origins in this outreach to the wider population, aimed at being less esoteric, more accessible and, today at least, more fun, and it continues to be organised by the descendants of Habib Swaleh, the Badawy family, who are scattered between Dar es Salaam, Mombasa, Mecca and Muscat. The festivities last for more than a week and the atmosphere is convivial. Donkey races, dhow races and various cultural activities, including the singing of qasidas and a Koran memorisation contest, lend the town a carnival atmosphere, whilst free medical care (several Badawys are doctors) and educational workshops represent the more serious social aspects of the event. It is a unifying event, with visitors from near and far. Not only does it consolidate the Hadrami diaspora, but since most visitors are probably not of Hadrami origin, it visibly reaffirms the prestige of those who are of Hadrami origin, as well as recognising their leadership, religious as well as secular, within the wider East African Islamic community. ${ }^{44}$

In 2012 I attended the Lamu Maulid and met a number of these people. One of them, Tahir, told me his story. He, too, was of Habib Swaleh's family, and although

\footnotetext{
${ }^{42}$ A.H. El-Zein, Sacred Meadows: A structural analysis of religious symbolism in an East African town (Evanstown: Northwestern University Press, 1974).

${ }^{43}$ Ibid.

${ }^{44}$ See also: Susan Beckerleg, "From ocean to lakes: Cultural transformations of Yemenis in Kenya and Uganda," African and Asian Studies, 8, 3 (2009), 288-308; Swalha Salim, "A History of the Yemeni Arabs in Kenya 1895-1963" (Unpublished MA diss., University of Nairobi, 1983); Iain Walker, "Citizenship and belonging amongst the Hadramis of Kenya," in Hadhramaut and its Diaspora: Yemeni politics, identity and migration, ed. Noel Brehony (London: I. B. Tauris, 2017), 164-86.
} 
originally from Lamu, in the early 1990s he had moved to Mombasa where he worked as a fish wholesaler; but being ambitious, and with the sponsorship of his uncles, Saudi citizens, he applied for and obtained a visa for Saudi Arabia. He worked for one of them for a while as a labourer before finding a job managing a department store. He spent five years in Riyadh but eventually got sick of it. "Riyadh is a 'sweet prison'," he told me. "You earn lots of money but you can't spend it, there's no alcohol [not that he drinks], no women." He realised it would take him 25 years to earn enough money to buy a house, and he didn't want to come back to Lamu as an old man to retire, having lived all his life as an expat. So, he worked long enough to pay off his debts to his uncles and returned to Lamu; he then moved to Dar es Salaam, where his father was imam of the Al Jamii mosque, generally referred to as the "Hadrami" mosque. He entered the import business, buying clothes and shoes from China (there are plenty of Hadramis in Guangzhou, he told me), Indonesia and Thailand, but as the competition grew, he gave up the business and found work in a managerial capacity with a motor vehicle importer.

This sort of trans-diasporic trajectory is quite common, and Tahir used his Hadrami contacts - uncles in Riyadh, his father in Dar es Salaam, Hadramis in Guangzhou - to make these moves. Tahir was just one of a number of people I spoke to in Lamu, some who came regularly, others who were there for the first time; some were from the Swahili coast or the Comoros, others from Hadramawt, Europe or India; some just had a vague family story that they were Hadramis but nothing else - no specific links, no tribal names - others had particular connections with Lamu and with Hadramawt. The maulid is clearly not just a religious event, it is also a diasporic event - it is about networking: renewing old ties, creating new ones, and not just for Hadramis, for it engages local communities, too, building hostlanddiasporic relationships. Nevertheless, given the history of the event, and the Hadrami origins of many of the region's scholars, many of those who come to Lamu are of Hadrami origin, seeking Hadrami acquaintances or kin. ${ }^{45}$

\section{Dar es Salaam}

The religious centres of Ngazidja and Lamu, economically and geographically peripheral to the principal commercial centres of East Africa, no longer have much to offer to the younger generation, and Tahir is just one of many who many who head for the region's cities. Although families of Hadrami origin - the Ash Shatry of Kilwa, for example - have been present in East Africa for centuries, many Hadramis trace their presence in the region

\footnotetext{
${ }^{45}$ Al-Junayd, $A l$ 'Uqūd; Le Guennec-Coppens, "Les masharifu," 91-102.
} 
to more recent times. Zanzibar, an important commercial centre in the late nineteenth and early twentieth centuries, attracted large numbers of Hadramis, many of them low status manual labourers. ${ }^{46}$ But the economic decline of post-independence Zanzibar, and the growth of Dar es Salaam since the late 1980s, has seen many Hadramis cross the channel to the mainland, joining others who were already there.

Ahmed's story is fairly typical of one who was already there. His father, Mafoudh, was from Hainin in Wadi Hadramawt, the main valley from which the region takes its name. His family was poor and had little land, and hunger and disease were part of life, and so, faced with few prospects and lured by tales of prosperity and success across the seas, Mafoudh decided to leave. He and a handful of other young men joined a caravan to the coast. After eight days' walk, they reached Shihr, where Mafoudh found a dhow and sailed for Africa. The journey was not a pleasant one: the dhows were crowded, food was rationed, the trip was long, and the seas were rough.

When Mafoudh disembarked in Dar es Salaam he found a well-established network of Hadramis ready to offer support to new arrivals. Almost all the older Hadramis I have spoken to have similar stories: taken in by a fellow Hadrami, sometimes kin, sometimes not, given work in a shop or loaned a little money to start a business. Some of these relationships were exploitative. One elderly man told how he had arrived as a boy and spent years living in a tiny shop owned by a Hadrami businessman, working seven days a week, earning a pittance: saving, and thus finding a way out, was effectively impossible. For others, things were easier, and Ahmed's father seems to have been one of the lucky ones, for he had close kin who treated him better than a stranger might have done. They loaned him some money and suggested he go to a village called Soga, about $30 \mathrm{~km}$ inland, a holding ground for cattle coming by train from the interior to the local wholesale markets; this he did, and he opened a small shop. His business thrived, and in a classic fashion: at harvest time he purchased crops from the villagers that he then took to Dar for sale to the wholesalers, usually Kutchis or Gujaratis, returning with goods, often bought at least partially on credit, for his shop. These goods he then sold to the villagers, again often on credit, thus establishing a durable relationship with both clients and suppliers the "host" community, even if others were also diasporic - playing the (undoubtedly stereotypical but nevertheless very real) role of the Arab shopkeeper in eastern Africa. ${ }^{47}$

\footnotetext{
${ }^{46}$ W. H. Ingrams, Arabia and the Isles (London: John Murray, 1942); G.H. Shelswell-White, "Notes on the Hadhrami and Shihiri Community in Zanzibar" (1935): Zanzibar National Archives, AB12/133.

${ }^{47}$ For the commercial activities of Hadramis in Kenya during the colonial period, see: Salim, "A History of the Yemeni Arabs." On the necessity of being an Arab to be a shopkeeper, see: Beckerleg, "From ocean to lakes," 288-308. Many
} 
As his business flourished, he opened a second shop, a butcher's, presumably a logical move given the cattle in the area, and he eventually became successful enough to move back to Dar es Salaam. There he married a local Hadrami woman - classically intradiasporically, the marriage was organised by the imam of the Hadrami mosque where Tahir's father is now imam - opened yet another shop and sent for his elder brother to join him. In 1956, Mafoudh was finally prosperous enough to take time off for a trip to the homeland. He performed the Hajj, and then paid a visit to his mother in Hainin. He spent eighteen months in his native village, where he married again, and he invested both affectively and substantially in the family and the farm: he rebuilt the family house, dug a well, installed a pump, bought them a Land Rover, and generally made sure the family were secure before leaving the farm in the care of his younger brother and returning to Dar es Salaam.

In 1966, ashamed that his son knew nothing of Hadramawt and its culture, Mafoudh sent young Ahmed back to the wadi. Sending a child, invariably a son, back to live with the family in the homeland had long been practice among Hadramis in East Africa, and like Ahmed, many were those who had been sent to Hadramawt as boys both to learn their culture and, as many put it, to avoid exposure to the less desirable influences of the Swahili world. ${ }^{48}$ These periods of education in the homeland generally lasted for several years. Kin at "home" shaped the boys' Hadrami identities, and the acquisition of cultural knowledge (including a knowledge of Arabic, often neglected in families with a Swahilispeaking mother) shifted the overseas-born Hadramis - the muwalladin, ${ }^{49}$ or "halfbreeds", as they are disparagingly referred to in Hadramawt - from a Swahili-focused identity to a Hadrami-focused one. Ahmed's stay was cut short, however: no sooner had he been enrolled in a local school than Hadramawt was annexed by the newly independent People's Republic of Southern Yemen, and he returned to Dar es Salaam. In Tanzania, however, the political context was little better. President Nyerere's socialist government had embarked on a process of nationalisation, and Ahmed's father's chain of nine butcher's shops were not exempt. Faced with the loss of his livelihood, Ahmed's father decided once again, and despite the communists, that a return home was called for. He took his entire family back to Hadramawt; but this time, instead of returning to his home in the wadi - the cultural heartland - he bought a house in the capital, Mukalla. This, too,

Hadrami shopkeepers in the East African hinterland also served as imam in the local mosque, thus, in customary fashion, combining the two roles of businessman and religious leader.

${ }^{48}$ Walker, "Hadramis, shimalis and muwalladin," 44-59.

${ }^{49}$ Literally "born" either elsewhere or to non-Arabs, or both, and by implication not fully Arab. 
is a classic solution to the issues that confront returning emigrants: finding neither the opportunities nor the social and cultural environment in the villages, they settle in the cosmopolitan port city: still Hadramawt, but in more anonymous surroundings, full of similar returnees; still the homeland, if not actually "home" - a spatially bounded transdiasporic community. ${ }^{50}$

\section{The Gulf}

Ahmed eventually finished his schooling and, drawn by the displays of wealth by Hadramis returning from Saudi Arabia and the Gulf, packed his bag and boarded a dhow to Dubai, where he found Hadrami kin and, through them, work. After four years in Dubai he moved to Abu Dhabi, where he obtained Emirati residence papers and trained as a technician with the state-owned oil company, ADNOC. He then went to the United States for a period of further study before returning to Abu Dhabi, where he worked for another Hadrami, Sheikh Ahmad Balluff, dealing in stocks, gold, and forex.

If the ports and hinterlands of East Africa, along with Southeast Asia, were preferred destinations for Hadramis in the pre-modern era, as Ahmed and Tahir's trajectories indicate, contemporary movements are more likely to be towards the Gulf. In the Arabian Peninsula, Hadramis find themselves in what is sometimes a curious hybrid land where it is often difficult to differentiate between diasporans and locals, between host and home. The former emir of Abu Dhabi and founder of the UAE, Sheikh Zayed bin Nahyan, was particularly well disposed towards Hadramis, claiming an identity between the Khaliji tribes and those of the Hadramawt, and in the early oil years (perhaps in response to an influx of non-Arab migrant labourers that threatened local Arab identities) gave many of them citizenship. Today there is a sizeable community of Emirati citizens of Hadrami origin in Abu Dhabi. Nevertheless, they retain a strong sense of tribal identity, and thus of Hadrami identity, and it is of course neither far nor difficult to return to Hadramawt regularly.

Abu Dhabi is a relatively new destination, but Hadramis have been present on the other side of the Arabian Peninsula for centuries - probably as long as they have been in East Africa. ${ }^{51}$ A small but influential community of Hadrami merchants and scholars had long been established in the Hijaz; but both these groups were close to the Sharifate and lost influence following the conquest of the Hijaz by Ibn Saud in the 1920s. They were replaced by "new" Hadramis, those who (often, according to narratives of origin that seem

\footnotetext{
${ }^{50}$ Walker, "Hadramis, shimalis and muwalladin," 44-59; Walker, "Comorians and Hadramis," 435-53.

${ }^{51}$ Field, The Merchants; Pétriat, Le Négoce des Lieux Saints.
} 
almost collective) walked from Hadramawt to Jeddah and Mecca, fleeing poverty, famine and disease in search of a new life. Finding work in Ibn Saud's kitchen, laying bricks for his new palace or, in the case of the Bin Mahfouz family, lending him money, from humble beginnings these men rose to become successful industrialists and bankers, and today their sons and grandsons are Saudi citizens, among the wealthiest people in the kingdom, very much part of the Saudi nation; but they have not forgotten their origins. ${ }^{52}$

If in Hadramawt members of the Hadrami diaspora are denigrated as muwalladin, in Saudi Arabia they are recognised as "pure" Arabs. There are two reasons for this. One is a slightly ambitious recognition that all "true" Arabs, descendants of Qahtan, are, ultimately, Hadramis, and that Hadramis are therefore at home wherever they are in the peninsula. This perspective underlies Sh. Zayed's claim of affinities between Khaliji Bedouin and Hadramis, even if this view is not entirely shared by Hadramis in Hadramawt, for whom an Emirati is an Emirati, even if of Hadrami origin. More importantly, however, is the fact that this perspective allows Hadrami women to move throughout the region. Hadrami women very rarely travelled overseas - to destinations fraught with impurity and danger - and Hadrami men were required to take foreign wives, thus producing muwalladin offspring. In Saudi Arabia, however, a woman has not left the Arabian Peninsula, and so virilocal residence rules (as well as patrilateral parallel cousin marriage preferences) make it perfectly acceptable for a Hadrami woman to marry, and move into the house of, a man living in Jeddah. Their children are therefore fully Hadrami.

However - and this is the reverse side of the claim that Hadramis are "at home" in Saudi Arabia - a Hadrami couple will raise their children as Hadramis, not as Saudis: both parents share a Hadrami identity. In truth of course the two identities - Saudi and Hadrami - have much in common and the diaspora/local distinction is perturbed. They speak the same language, they share a tribal culture, they have similar kinship systems, even their material cultures have much in common. And in the process of growing up in Saudi Arabia, Hadrami children are also socialised as Saudis: Saudi Hadramis become Saudis of Hadrami origin. Nevertheless, and although in the contemporary era air travel has rendered distances less tyrannical, the proximity of Hadramawt also allows for more regular visits than their kin in, for example, Ngazidja might be able to make, and during the holiday season large four wheel drive vehicles with Saudi licence plates are a common sight on the roads of Hadramawt as "Saudis" visit their families in the homeland, many of

\footnotetext{
${ }^{52}$ I have written elsewhere about Hadrami belonging in Saudi Arabia. See: Walker, "Hadrami identities in Saudi Arabia," 42-60. On Saudi Hadrami's relationships with the homeland, see also: Pritzkat Stadtentwicklung und Migration.
} 
whom are of course diasporans themselves. ${ }^{53}$ These returns, in which diasporans from elsewhere encounter one another, maintain and reinforce the trans-diasporic networks that bind the different localisations of the diaspora together, all while sustaining the links with the homeland.

\section{Home: A Conclusion of Sorts}

Relationships between diasporans and people in the homeland are often fraught, and for many of those who return the pattern is fairly predictable: the muwallad arrives in Hadramawt and heads for the home village, where he is welcomed with open arms. ${ }^{54}$ After a couple of weeks, it becomes clear to his hosts that some of his practices (such as wearing jeans) are undesirable and that he does not come bearing riches; on the contrary, he may be trying to invoke ancestral claims on a house or a date plantation. As for the muwallad, he rapidly realises that life in a small village in Hadramawt is not as exciting as Mombasa, while questions from his kin about how long he plans to stay make him realise that he is perhaps not quite as welcome as he thought. Eventually he returns to Mukalla, to find likeminded muwalladin from East Africa and, eventually, a job. Often, thanks to his education and his knowledge of English, he succeeds in the latter, landing, for example, a (relatively) well-paid position with an oil company, thus earning the jealous resentment of the family in the village. ${ }^{55}$

Other relationships are less fraught: a visitor to almost any village in Wadi Hadramawt can find, after the asr prayer, a small group of old men sitting together, drinking tea and chatting in Swahili or Malay. These people are often regarded with wry amusement, and older people generally, whether on temporary visits to see friends and family or "home" for good, are tolerated; but there nevertheless remains an ambivalence in the relationships between homelanders and diasporans that is difficult to dissipate. Many diasporans still send remittances, particularly those in the Gulf, and may contribute in kind when they visit; but at the same time there is a constant threat, both social nefarious influences from the outside world in what is considered a bastion of tradition and religious conservatism - and economic, for there are indeed people who return looking for a forgotten inheritance. This is part of the diasporan discourse: "we have a

\footnotetext{
${ }^{53}$ Or were: although there is direct access to Hadramawt from Saudi Arabia through the Al Wadiyah border post, the war in Yemen is certainly affecting movements in the region.

${ }^{54}$ In addition to the texts mentioned in footnote 52, see: Ho, "Hadhramis abroad in Hadhramaut," 131-67; Ho, The Graves of Tarim.

${ }^{55}$ Walker, "Hadrami shimalis and muwalladin," 44-59.
} 
house and a date plantation in Hadramawt, we can go back whenever we like"; but often, of course, they don't, and they can't, and they know this. ${ }^{56}$

As we have seen, the Gulf also attracts muwalladin, Hadramis from East Africa who are both "Africans," and thus assimilated to the population of migrants whose rights are limited and movements restricted, and "Hadramis," and thus recognised socially by their fellow diasporans. Some follow more formal migrant labour trajectories, obtaining sponsors and job offers before leaving Mombasa, others pass through Hadramawt on their way from Ngazidja to Jeddah in order to acclimatise, perhaps, to the Arab world: meet kin, establish some contacts, and learn some "proper" Arabic, activating trans-diasporic relationships as well as those with the homeland. With a foot in both worlds, they draw upon various identities, and follow a variety of trajectories, but many of these trajectories are inscribed within the Hadrami diasporic world. Thus Ahmed, while living in Abu Dhabi, returned to Dar es Salaam to seek a wife, eventually marrying his mother's sister's daughter: a muwallad from the next village in Hadramawt, but also from Dar es Salaam, a Hadrami with a Swahili perspective on the world, or perhaps a Swahili with a Hadrami perspective on the world. Links with the homeland are reinforced through diasporic practices, and Ahmed continued to reinforce them, sending (slightly unusually) his daughter back to Hadramawt for an education, fearing Abu Dhabi was too modern and too decadent for her. "I'm broad minded, in thinking, in theory" he told me, "but practically I become very narrow minded. I want my girl to be brought up the way our parents wanted us to be brought up. Maybe if my father hadn't brought me here in the 1960s, I wouldn't care about this culture." Here Ahmed quite explicitly explains his diasporic perspective with reference to his father's diasporic practices: just as his father sent him "home" to become a good Hadrami, so he did likewise with his daughter.

So Ahmed, too, finally went "home," returning to Mukalla where he lives with his wife and his elderly mother, both of course "from" Dar es Salaam; and despite all the diasporic embedding, Ahmed explained that, prosaically, he returned to Mukalla to look after his mother who, through the vicissitudes of diaporic mobilities, had ended up there rather than Dar, Abu Dhabi or even Hainin. Ahmed's biography illustrates well the complexity of these diasporic mobilities: an initial migration in a context of very little choice, voluntary return visits, another migration prompted by political events, the economic attractions of Abu Dhabi, the multiple pulls exerted by the homeland and diasporic homes, and by the people in his entourage, his ageing mother and his wife, kin

${ }^{56}$ Walker, "Comorians and Hadramis," 435-53. 
both close and distant, Hadramis and others, whoever they may be. It also illustrates the ambiguous place of the homeland: central, perhaps, but also just another site on diasporic trajectories. Ahmed could have remained in Abu Dhabi or returned to Dar es Salaam, both places where he and his wife (and presumably even his mother) were embedded in networks of kin, fellow diasporans and "locals," and very much "at home." And it illustrates - once again - how people move through Hadrami diasporic networks, many of whose members did not move; for if people are to move through diasporic networks there must also be people who do not move, who constitute the more stable nodes of these very networks, but who remain imbricated nevertheless. In turn, these trans-diasporic relationships are both maintained and reinforced by those who do move, providing scope for a reconstitution of Hadrami identities that draws upon different diasporic localisations. New technologies in particular have facilitated diasporic cohesion, although perhaps not transformed them - it is easy to forget that people managed to communicate quite effectively before the invention of email, never mind Twitter - witness Ahmed. All these movements and practices also illustrate very well the four fields of diasporic action that I identified above - the intra-diasporic, the trans-diasporic, the homeland-diasporic and the hostland-diasporic - and how ultimately the homeland is just another diasporic site.

The theoretical framework that I have developed in this article, and which I suggest provides for a more rigorous and more useful definition of a diaspora, is based on a single case study, that of the Hadramis. My ethnography does not permit me to argue with any confidence for the existence of other such "diasporas for others," but I strongly suspect that there are: Gujaratis, Tamils and Chinese (be the latter a single diaspora or several), are certainly all potential examples of the sort of spatially discontinuous and temporally persistent community that could usefully be thus analysed. ${ }^{57}$

Furthermore, I have largely been concerned with the socio-cultural, affective and practical aspects of Hadrami identities, less so with the formal ones. I have tried to avoid referring to transnationalism, states, citizenship, passports and visas, talking about Hadramis in Ngazidja, Lamu and Dar es Salaam rather than Yemenis (for citizens many are) in the Comoros, Kenya and Tanzania. ${ }^{58}$ This is not to suggest that these things are not important. Indeed, the character of the state itself is clearly very important: capitalist Dubai, in the United Arab Emirates, presumably had more to offer a young man seeking

\footnotetext{
${ }^{57}$ On the possibility of 'several' Chinese diasporas, see: Federica Guccini and Mingyuan Zhang, “'Being Chinese' in Mauritius and Madagascar: Comparing Chinese diasporic communities in the western Indian Ocean," Journal of Indian Ocean World Studies, 5, 1 (2021), 91-117.

${ }^{58}$ The crossing of borders is not analytically intrinsic to diasporic movement even if, with exceptions such as members of the Hadrami diaspora in other parts of the Republic of Yemen, it is largely inevitable.
} 
to make his way in the world than Marxist South Yemen might have done. There are clearly constraints on movement, too. Almost every Hadrami I have met has a passport or two, and presumably needs to have his or her papers in order to travel through these diasporic spaces; and I know many of them have encountered obstacles. But I am equally impressed by the apparent ease with which people do move, and I have written about this before. ${ }^{59}$ But I say very little about people's formal identities, because they are rarely made explicit and are not particularly relevant to people's narratives and to the outcomes (if not the logistics) of their trajectories. Many of these locations are already "cosmopolitan" places and possessing multiple affiliations is not uncommon. People may reveal that they have two or three passports, but if they essentialise, and self-essentialise, this is largely for practical purposes, and whether (or perhaps more importantly, when) they consider themselves to be Hadramis, Zanzibaris, Wangazidja or Hijazis is contingent. I have not tried to define any of these people, not even a Hadrami, and I suspect have no need: it should be clear by now that a Hadrami is simply someone who is part of this "diaspora for others."

${ }^{59}$ Walker, "Hybridity, belonging, and mobilities," 167-78. 